\title{
THE CONCEPT OF TOLERANCE IN ISLAMIC EDUCATION
}

\section{Adeng Muchtar Ghazali}

State Islamic University (UIN) Sunan Gunung Djati Bandung

Jl. A.H. Nasution No 105 Bandung, West Java-Indonesia

Email:amgy@uinsgd.ac.id

\begin{abstract}
This article aims to discuss comprehensively the concept of tolerance in Islam later thought in such a way that the concept can be applied operationally in Islamic educational institutions such as madrassas, Islamic boarding schools and colleges. Methods and approaches used to address this issue are philosophical (phenomenological) and the sociology of education, one of which is the theory of inclusivism Mircea Eliade. In Islam, different thoughts, tribes, and even religion (adherents) refer to fitrab and sunnatullahb of God's will. For this reason, then, tasamuh (tolerance) becomes an important doctrine in every religion treatise, including in Islamic education system i.e; 1) to have responsive toward modernization which has been existed in general school institutions under Ministry of Education; 2) to develop sensitive character toward the change through apporiate learning strtategy and developing children psycho-social condition, modernizing learning facilities, environment, and other supporting factors including the involevement of parents, government, society and other education stakeholder; 3) to implement a model to strengthen inclusive Islamic education system which is opened, dialogic, and student-centered; 4) to bear a strong and tough human reseource with high tolerance who will act to occupy and create new civilization emphasizing on religion, spritual and humanism values; 5) to develop networking and corporation both national and international to expand informationn access, funding, and other international supports.
\end{abstract}

Keywords : Pluralism, Tasāmuh, Inclusive Islamic Education

\begin{abstract}
ABSTRAK
[Artikel ini bertujuan membahas secara komprehensif konsep toleransi dalam Islam kemudian berpikir sedemikian rupa bahwa konsep dapat diterapkan secara operasional di lembaga pendidikan Islam seperti madrasah, pondok pesantren dan perguruan tinggi. Metode dan pendekatan yang digunakan untuk mengatasi masalah ini adalab filsafat (fenomenologi) dan sosiologi pendidikan, salah satunya adalah teori inklusivisme Mircea Eliade. Dalam Islam, pemikiran yang berbeda, suku, dan bahkan agama (penganut) mengacu pada fitrah dan sunnatullah dari kehendak. Tuhan. Untuk alasan ini, maka, tasämuh (toleransi) menjadi doktrin penting dalam setiap risalah agama, termasuk dalam sistem pendidikan Islam yaitu; 1) responsif terhadap modernisasi yang telah ada di lembaga sekolah umum di bawah Departemen Pendidikan; 2) mengembangkan karakter sensitif terhadap perubahan melalui apporiate strtategy belajar dan mengembangkan anak-anak kondisi psiko-sosial, modernisasi fasilitas belajar, lingkungan, dan faktor pendukung lainnya termasuk involevement orang tua, pemerintah,
\end{abstract}


masyarakat dan pemangku kepentingan pendidikan lainnya; 3) menerapkan model untuk memperkuat sistem inklusif Islam pendidikan yang dibuka, dialogis, dan berpusat pada siswa; 4) menanggung reseource manusia yang kuat dan tangguh dengan toleransi yang tinggi yang akan bertindak untuk menempati dan menciptakan peradaban baru yang menekankan pada nilai-nilai agama, spritual dan bumanisme; 5) mengembangkan jaringan dan perusabaan baik nasional maupun internasional untuk memperluas akses informationn, pendanaan, dan dukungan internasional lainnya].

Kata Kunci: Pluralisme, Tasāmuh, Pendidikan Islam Inklusif

\section{INTRODUCTION}

Recently, an emerge phenomenon in national and religious life is by facing a big challenge due to intolerance action (nirtoleran). The nation which is known as having civilized, religious, and qualified in unity as well as high and strong tolerant characters, is getting eclipsed slowly by various national and local incidents from, a bombing case by terorist group which always be on behalf of "religion struggle" (jihad) to the fight among students or citizens. Those incedents have become a serious attention of President Susilo Bambang Yudhoyono, which lately revealed it when he opened Musyawarah Perencanaan Pembangunan Nasional (Musrenbangnas) on 28th April, 2011 in Wisma Bidakara Jakarta Selatan. The President said that "security disturbances due to terorism, horizontal conflict, and radical movement motivated by religion have become a serious threat. Therefore, citizens are invited to be responsible to save national character especially for young generation". Furthermore, the president stated that "the prevention of security disturbances cannot be submitted to Polri and security apparatus. Regent and mayor must also play an active role to observe such anomaly in the society". (Pikiran Rakyat, 2011, p. 1).

It is realized that Indonesian people are pluralistic society which cannot be avoided from reality. This diversity is admitted in constitution which guarantees all different religion adherents to do their doctrines based on their faith. However, the diversity of religion adherents and cultures can have a potential conflict that leads to be a disaster. As in social reality, this religion plurality sometimes become a problem in which in one side, religion is considered as an autonomous personal rights, on the other hand, this right has a complex social implication in society life. Each religion adherent believes that their doctrines and values must be proclaimed in society and national life (claim of truth). In this context, religion often become a potential conflict in the society. Based on these empirical-historical facts, religion plurality is impossible to be avoided. Nurcholis Madjid attempted to remind that plural value system is God's rule (Sunnatulläh) which cannot be changed, 
fought, and denied. Those who try to deny culture diversity law, it will cause continuous conflict phenomenon (Madjid, 1995, p. 47).

Based on religion plurality, recently, the big problem in religious life is how a particular theology can define itself among other religions. The understanding on religion plurality is getting developed more and more. This leads to the development of ideology known as teologia religionum, i.e., an ideology which emphasizes on the importance to understand theology in religion contexts in this era (Kartika and Mahendra, ed., 1999, p. 129-130) but at the same time, it still preservers its faith and truth. This shows that religion faith is an unnegotiable matter, moreover, it cannot be changed. Religion is not like house or clothes which can be changed anytime. If someone has particular faith, then, its faith will not be separated from him. He will be involved with his religion faith (Rasyidi, 1968). Thus, the understanding on plurality is not always related to theology matters or faith but it only gives a place and confession for other religion existence. Pluralism's view does not refer to the truth in other religion. Indeed, It definitely does not discuss about it. Furthermore, it does not consider the mistakes on other religion theologies.

In context of religious plurality life as mentioned previously, in order to preserve diversity on religion faith in harmony context, it is needed to have mutual understanding and respect atmosphere among all various religion adherents. One of the ways to have all of them is by doctrine regarding different religion and faith principles. Each religion, especially Islam, has owned these basic principles. This religion tolerance is not only refers to norms in each religion but also it comes from personal experience of religion adherents both directly and indirectly of religious phenomenon.

This article aims to explore the concept of tolerance in Islam later thought in such a way that the concept can be applied operationally in Islamic educational institutions such as pesantren, madrassas, Islamic boarding schools and colleges as well as Islamic University. Methods and approaches used to address this issue is phenomenological philosophy and the sociology of education, one of which is the theory of inclusivism Mircea Eliade.

Phenomenologically, religious pluralism refers to the fact that religious history shows a plurality tradition which has variants on each tradition. Meanwhile, Philosophically, religious pluralism refers to particular theory of relationship among those various traditions. The theory is related to the relationship among religions in the world which shows conception, perception, and respond to the only one ultim, a full mistery of God's reality. In addition, such theory is approached at least by two main methods, exclusivism and inclusivism (Eliade, 1987, p. 331). In other words, pluralism cannot be understood by saying that our society is plural or diversed which 
has various tribes and religions. This, of course, bears a fragmentation image, not a pluralism. Moreover, pluralism cannot be realized as a negative good which only views on its function to remove fanaticism. However, pluralism must be understood as "a pure relationship of diversity in refinement bond." In fact, pluralism becomes a must for human's salvation, especially, through monitoring and balancing mechanism (Rahman, 2001, p. 31).

\section{DISCUSSION}

The term of tolerance comes from English "tolerance" or in Latin "tolerantia". In Arabic, it refers to tasämub or tasābul means; to overlook, excuse, to tolerate, to be indulgent, tolerant, forbearing, lenient, merciful. The word tasâmah; has meaning bilm and tasähul; meaning indulgence, tolerance, toleration, forbearance, leniency, lenitt, clemency, mery and kindness (Baalbaki \& Al-Mawrid, 2004, p. 314). Related to another religion, historically, the term tolerance is also called "toleration", which was analyzed for the first time by John Locke (1963) in the context of relation between church and nation in England. Toleration, here, refers to the readiness no to interfere one's faith, attitude, and action although he is not liked by other. The nation cannot be inlvolved in one's religion affair and it cannot be handled by particular religion group (Mujani, [n.d], p. 159). Meanwhile, the term "harmony" in Kamus Besar Bahasa Indonesia published by Department of Education and Culture, is defined as "live together in the society with heart unity and agreement not to create a conflict." Harmony is the term containing "good" and "peace" meaning. The point is to live together in society with united heart and agreement by avoiding a conflict (Depdikbud, 1985, p. 850). If this definition becomes a reference, "harmony" will be something ideal and covetted by human beings.

In Islam, the term tasamub is not basically the same meaning with the word tolerance, because tasammb has meaning to give and to take. Tasamuh includes giving action and demand in particular limitation. Tasämuh contains hope in one side to give and take at once. The subject does tasämuh in Islam namely mutasämibin, meaning "forgiver, taker, offerer, giver as host to guest". In the implementation, a person who does tasämub is not only doing to give that will push his rights and obligation. In other words, tasamub attitude in religious life has definition not to break the limit, especially related to the faith limit (aqidab). Although tasamub has the meaning mentioned above, in many context, this word is often the same with tolerance. Holy Qur'an never mentions the word tasamub/tolerance in its letter and verses. However, holy Qur'an explain explicitly the tolerance concept with all of its boundary. Thus, in the implementation, the verses related to tolerance concept can be a reference for our life. 
In Indonesian dictionary written by Poerwadarminta, the word tolerance shows meaning "sincere (to like everyone, to let everyone give opinion or have another arguement, not to disturb one's freedom of thought and faith)" (WJS Poerwadarminta, 1996, p. 4010). In this context, tolerance can be formulated as one of oppeness attitude to listen different view which functions two ways, i.e., to give opinion and take another opinion and not to disturb other's faith in the agreement scope.

The definition of tolerance above has the same meaning for the word tolerance in UNESCO-APNIEVE book for teacher education and higher education in which "tolerance is a respect, gift, award of richful diversity for our culture, our expressions, and our ways of life as human beings". This definition means that it is needed knowledge, oppenness, communication, consienceness, and trustworthiness in order to realize and preserve tolerance. Therefore, tolerance is "harmony in difference" which not only requires moral obligation but also politic and law requirement (UNESCO-APNIEVE and UPI, 2000, p. 154).

In the relation to political and law actions, tolerance sues fair and impartial Acts, law establishement, court and administration processes. Excommunication and marginalization can lead to frustration, hostility, and fanticism. To make society has tolerant attitude and action, UNESCO suggests that every country ratifies the available convention of international human rights and composes new Acts to guarantee an equal treatment and opportunities for all of groups and individuals in the society (UNESCOAPNIEVE and UPI, 2000, p. 155).

In religious life, tolerant attitude becomes one of primarily requirements for each individual who wants to live together securely and rescpectfully each other. Thus, it is expected to realize a good interaction and understanding in the religious society regarding their rights and obligation boundaries in social life which consist of various different tribes, races, religions and faiths. Nevertheless, the implementation is not simple as it is although the explanation of tolerance definition has contained formulation of appreciation for other's existence. There are still many problems on which approach should be applied in creating a harmony society especially related to different religion and faith problem. Thus, it can be concluded that this tolerance leads to oppeness and willingness attitudes to admit the diversity of tribes, skins, languages, traditions, cultures and religions.

In sociological, Islam doctrine related to tolerance is conformable with the reality of religious plurality existence. Different faith is social reality which cannot be denied. The acknowledgement of religious plurality in sociological becomes the simpler tolerance admission but this admission 
does not contain of admission toward the truth theology of another religion (Q.S., 2: 251).

Schumann (2006,p. 84) mentions that there are five dimensions of tolerance among religion adherents which have related to each other, they are; 1) social practical dimension, the openness to accept empathically the existence and activity other religion adherents in all aspects of life which are guided by ethic-moral doctrines in each religion; 2) religious ritual dimension, the openness to accept empathically the ways and methods of symbolic ritual expressions in religious life from other religion adherents; 3) doctrinal dimension, the openness to understand empathically the statements and doctrinal/aqidab claims which are believed by other religion adherents which are sourced from holy book and religious traditions that are getting actualized and developed became; (a) pilgrimage of religious life dimension. The openness to admit each other that every religion adherents is doing a pilgrim or religious life, beginning from primarily generation of each religion based on its social context history and continuouing by each contemporer religion adherent creatively and dinamically based on its social context; (b) spirituality and religiosity dimension. Every part in relations of religion adherents requires to meet closely and intimately with transcendent Reality, i.e., spiritual reality, which becomes the center of spiritual that brings motivation for life in goodness and affection to human beings-motivation which makes tolrance among religion adherents as a spiritual duty.

Besides several problems causing inharmony among religion adherents, other factors that becomes barrier of tolerance come from the internal religion adherents which influence the intercommunication among them. Those factors are described as follows;

1. Religion understanding. Most of the emerge religion problems lie on interpretation problem or understanding and it is not based on the truth of religion or God's revelation itself (Andito, 1998, p. 58). Thus, the religious harmony including dialogue among religion adherents must be a sociological discourse by placing religion doctrines as the basic for precious humanity development. According to Ninian Smart, the increase of knowledge or understanding will cause to weaken hostility and in this stage, it means to increase agreement (Permata, 2000, p. 151);

2. Truth claim. Every religion has owned the truth. This faith of truth is based on God as the only source of truth. In sociological, truth claim is changed to be a religion symbol which understood as subjective personally by each religion adherents. Apparently, everyone is difficult to release a subjectivity frame when personal faith is faced to another different faith. even though it is natural, it is impossible that everyonne can put two contradictory things in his heart deeply. Therefore, every 
religion adherent cannot force his inclusivism to another one which is considered exclusive to us.

3. Double standars. Hugh Godard, as quoted by Rahman (2001, p. 34), a Christian and an expert on Islam theology in Nottingham University, England, gives an example that "the relation between Christian and Islam which is developed into misunderstanding, in fact, it creates a threat situation between them is a condition of double standard. Both Christians and Moslems always apply different standards for themselves whereas they use another standard which is more realistic and historistic to another religion. For example, in theology problem, there is a standard that creates truth claim problem: "Our religion is the most truth one because it comes from God but other religions are just human's creation. They may come from God but it has to be damaged abd faked by human beings". In history, this double standard is usually used to judge another religion in validity degree theology under its religion. Through this double standard, we can see some emergences of theology prejudices which can disturb the relation among religion adherents.

4. To exaggerate differences. Nowadays, the religion challenges become problem and barrier for having a harmony atmosphere and dialogue among religion adherents. In viewing and understanding the development of religious plurality life now, it is generally perceived its different rather than its common. However, the tendency to perceive such view cannot be blamed because every religious person always wants to seek, to hold, and to defend his truth based on his knowledge and tradition. Such attitude is very excellent as long as it will not cause destrcutive social situation (Andito, 1998, p. 97). Emphirically, it is impossible if we idealize the emerge of the only one truth by only one format and wrap and then it is caught by human beings with the same and only undertsanding and faith. Thus, the challenge which is always faced is how to formulates constructive step operationally to reconcile all religions which tends to bear arguments among human beings in the name of God's truth.

\section{Tolerance in Islam Perspective}

Islam views that those differences mentioned above are fitrah and sunnatullah or it has become God's will. This theoretical foundation is based on Allah Swt's commandement (Q.S., 49: 13). As God's will, this difference and plurality must be accepted by all human beings. Such acceptance must be properly appreciated by sincerly to follow God's guidance. Those who cannot accept plurality means denying God's will. For this readon, tolerance becomes an important doctrine in every religion, including Islam teology system. According to Ismail R Faruqi in his book edited by Altaf Gauhar 
(1983, p. 120-121), it is said that Islam has its owned norms to have a diarect dialogue among other religions. This dialogue is not only for changing information, ceremonies or politeness but also it must have religious norm that can conciliate various differences among religions. According to him, Islam finds this norm in din al-fitrah. Based on this basic norm, Islam has strong theory with Jews and Christians which are not considered as "other religions" but they become part of itself. Abraham's religion unity: Jews,Christian and Islam is based on hanifi concept, din al-fitrah, which is a real possibility. Yusuf Al-Qaradlawi (1997, p. 274) states that Islam teaches dialogue when there is different opinion and in fact, different opinion is a Sunnatulläh which has been set for all of his creatures. Islam not only teaches dialogue but also gives norms and ethics in dialogue by using good ways which is parallel to basic dakwah method (Q.S., 16: 125).

According to Azyumardi Azra, there are two things related to perspective on Islam theology regarding a harmonous life among religions and its concequences among religion adherents. First, Islam doctrine about the relation among human beings and the relation between Islam and other religions; second, historical experience of human beings themselves in the relation with other religions followed by people (2006, p. 92). In doctrinal, Islam essentially views human and humanity in very positively and optimistically. Based on Islam, human beings comes from the same source, i.e., Adam and Hawa's descent. From this root, human is developed into tribes, nations completed by its typical culture and civilazation. This different encourages human to know each other and to grow an appreciation as well as respect each other. In Islam perspective, the differences among human beings are not due to skin colors and nations but it depends on its taqwa level. (Q.S., 49: 13). This becomes basic Islam perspective for "human unity", which encourages to develop solidarity among humans (ukhuwwah insaniyyah or ukhumwah basyariyyah and ukhuwah wathaniyah). Ukhuwah insaniyah is related to human brotherhood universally without differentiating tribes, races, nations, and religions and other special aspects; whereas ukhuwah wathaniya refers to fraternity bounded by nationalism without differentiationg religions, races, traditions, and ther special aspects (Wahyudin et al, [n.d]., p. 93).

Concept of tasamub or tolerance in diversity of life basically is one of primary attitudes and behaviour acceptance toward God's will. The religious tolerance does not mean to have freedom on following one particular religion for today and change into another religion in the next day. This does not also mean to have freedom on doing various practical and ritual religion without following the rules. However, it must be understood as an acceptance form toward the existence of other religions besides his religion 
with all system forms and ways of worship; and it also gives freedom to do his faith without conflict in social life due to the faith difference.

The definition of tasamub or tolerance in religious life offered by Islam is so simple and rationale. Islam obligates its followers to build a strict boundary in aqidah and faith as well as keeping appreciation principle toward the existence other religion followers and respect their rights as individual and part of society. This strict boundary in aqidah or faith shows Islam's effort to keep all their adherents so that they will not be trapped in syncretism (Hamka, 1983, p. 264). In the last verse of Sürat al-Käfirün, it states firmness that tolerance attitude has boundaries especially in the relation of aqidah. Islam doctrine strictly forbids its adherents to act as other religion adherents (QS. Al-Hadīd: 16). At the same time, Islam proclaims to respect and consider the religious differences as individual with all rights and obligations that must be appreciated. Islam forbids its adherents to scold other people, forbids any attitude forms that can harm life togetherness in a society (QS. Al-Hujurât: 12).

Several verses on Holy Qur'an can be sourced as basic principle of tolerance (tasamuh). Besides that verse mentioned above, there are some other verses which show tolerance, among others QS. An-Nahl: 125, Ali-Imrân: 19, Yunus: 99, Al-Mumtahanah: 8-9, and Al-Kahfi: 29. The most important thing in understanding on tolerance cumpolsion in this religious life is by following attitude and behaviour of prophet Muhammad Saw in his entire life. There are some sunnah related to his command for his adherents in order to keep their attitude and behaviour so that they will not break humanity boundaries even though they have different faith. The agreement between prophet Muhammad Saw and Christians in Sinai Mountain is one of examples of tolerance attitude which admit the existence of religious plurality in the society (Rahman, 2010). Another example of Islam tolerance taught by prophet Muhammad Saw is when fath Makkah was conquered by Moslem in Ramadhan month. It took 21 years to release Mecca from musyrikin authority. When Moslem celebrated their euphoria, there was a small group of prophet's comrade who did a parade by yelling a slogan al-yaum yaum almarhamah. This slogan is intended to be a revenge for musyrikin's cruelty to the previous Moslem. Such incident was immediately anticipated by prophet Muhammad by forbidding the slogan and changing it into, al-yaum yaum almarhamah, thus, Mecca's freedom can be realized without any violence incident. This is also supported by Said Aqiel Siradj that "Islam is open minded and inclusive faith. It is not an intolerant political ideology and it does not force human to be its adherents" (Republika, April, 14th, 2007).

If tolerance in religious life taught by Islam to its adherents is implemented appropriately, it will bear inclusive, open minded, friendly Islam 
which is properly fitted with nubuwwah mission; Islam rabmatan lil 'älamin (QS. Al-Anbiya: 107). If this tolerant attitude is taught and implemented well, it will make people realized that there is no forcement in following particular religion (QS. Al-Baqarah: 256), moreover, the act to threaten someone's safety will not be occured. Similar to the aspect on not having forcement in religion, T.W. Arnold in his book the Preaching of Islam (1993, p. 279-280) stated that "forcing is not the only determinant factor in religion conversion, as it is showed by the good relationship between Christians and Arabic Moslems. Prophet Muhammad Saw himself did some agreements to the Christians by promising protection to them and guarantee their freedom to do worship, furthermore, to the Church, Prophet promised not to disturb their existence rights and authority". In other words, tolreance or tasamub is one of the primary doctrines which equals to other doctrines such as affection (rahmah), widom (bikmah), universal welfare (maslahat al-ummah), fairness $(a d D$. Some of those primary doctrines in Islam are something called qath'iyyat in ushül al-fiqh meaning it cannot be cancelled by any reasons, and kulliyyät, which is universal, passing space and time (shälib li kulli zamän wa makan). Shortly, the Islamic primary principles has trans-historic, transideology, and trans-faith-religion characters.

Islam with this tolerence in continuity becomes a manifestation of universal Islam values as religion for all human beings. Tasamub which is taught by Islam will not destruct the holy mission of aqidah, but it becomes a confirmation of Moslem personality in the middle of religious plurality life. Therefore, Islam in one side can be said to have more respect on individual who is responsible socially without leaving his primordial values as Moslem. If the core of religion doctrine is not to ally Allah Swt, to do good things, to have faith for final judgement day, thus, tolerance attitude is one of missions contained in that core of kindness. Therefore, there are many verses in holy Qur'an which is connected between faith and kindness, among others: "verily man is in loss, Except those who believe and do righteous deeds, and recommend one another to the truth, and recommend one another to patience” (QS. Al-'Ashr: 1-3).

Nurcholis Madjid has commented on the importance of tolerance as the realization of Islam rahmatan lil 'alamin in journal Ulumul Qur'an (1993, p. 16) which states that inclusivity views is required for nowadays since the development of knowledge and technology advance has taken human beings to live in global village. In that global village, as it has been mentioned, humans will be more intimate in knowing each other but also it will be easier to face a direct confrontation. That's why it is required to have mutual understanding attitude by seeking the similarity point or kalimatun sawa' as commanded by Allah in the holy Qur'an. Firmly, holy Qur'an forbids 
forcement of particular religion to other people or community even though that religion has owned truth since only Allah at last who will guide someone personally. Nevertheless, for the sake of his happiness, humans must be opened to every doctrine or view, then, he is willing to choose the best one.

Tolerance principle which is realized in the form of harmony life, can be seen in several contexts: first, universal humanity brotherhood, i.e., all human beings are in the same descent. Second, Islam teaches that human was born in holy condition (fitrah). In his fitrah, everyone is blessed by potentiality and tendency to look for, to consider, and to understand the truth which finally make him be able to admit God as the truth source. These potentiality and tendency are called hanif (QS. Ar-Rûm: 30). Based on this principle, Islam proclaims that every human beings is homo religious.

Islam obligates its adherents to convey Islam's messages through dakwah, i.e., a summon of truth which makes human can reach salvation both in the world and afterlife (QS. An-Nahl: 125, Al-Hajj: 67 \& As-Sajdah: 33). Since dakwah is a "summon", as a result, he cannot involve forcement - la ikräha fi al-din (QS. Al-Baqarah: 256). Clearly, Islam admits other religion life rights; and justifies other religion adherents to do their religion doctrines. This becomes the basic Islamic doctrine for religious tolerance (Sairin, 2006, p. 94). In addition, Islam obviously teaches tolerance which refers to holy Qur'an, tolerance is al-sambah meaning easy based on easiness. As it is stated in holy Qur'an that "Allah has chosen you and has not laid upon you in religion any hardship, it is the religion of your father Ibrahim. (QS. Al-Hajj: 78).

In education context, tolerance principles which have very strong theology root can be transformed to learners comprehensively in the house, school and society environment which finally they can implement tolerance attitudes. Education is the most proper tool to avoid nirtolerance (UNESCOAPNIEVE \& UPI, 2000, p. 156). The reason is because education teaches people about the rights and their freedom to respect and protect each other. Thus, education for harmony and tolerance must be viewed as urgent impertive doctrine. For that reason, it is required a systematic and rationale methods and materials for harmony and tolerance learning so that the harmony and tolerance values among religion adherents are not based on actions for "security stability" interest but it is more than that; the harmony and tolerance action must be based on religious awareness. The strengthening on internalization of tolerant attitude to learners will result tolerant, peaceful, and rahmatan lil 'älamin citizens. 


\section{Implementation of Tolerance on Islamic Education}

Some of basic values for harmony life among religion adherents, as it was stated previously, are sinergized with basic Islamic education principles, namely, openness, affection, harmony, and intergrity principles (Kodir, 1993, p. 154). These basic Islamic principles is primary idea born from the human's meaning ins Islam perspective which has an implications on practical education action. A further big task is how Indonesian Moslems have religious tolerance attitude who can build superior and modern civilization with full of peaceful without loosing their culture root and cultural characteristics.

Islamic education system is developed by applying moderate Islamic understanding conceptionally so that learners have strong tolerance character. By understanding plurality society in the reality, the education concept developed in Islamic education institution is understanding, spirit, and management which are able to accomodate the difference and diversity without sacrificing each individual's faith religion.

Syamsul Maarif in his writing entitled "Islam dan Pendidikan Pluralisme, Menampilkan Wajah Islam Toleran melalui Kurikulum PAI berbasis Kemajemukan", a paper written in Annual Conference of Islamic Studies, Lembang Bandung, November 26th-30th 2006, stated that "Islam religion education cannot only be understood as "religion teaching" or its successful parameter of religion education is not sufficient to measure it only based on how learners can acquire cognitive things or only religion doctrine knowledge or religious rites. Moreover, the assessment is given through numbers based on how can the students acquire the material from handout book. Nevertheless, the more important thing is that how deep the religion values can be applied in their souls and how deep those values can be realized in the students' attitude and behaviors in daily routines. The real form of those values in daily attitudes and behaviors will bear good behavior (al-akbläk al-karimab). Thus, religion education is an education for religion total growth of human being. This is also supported by Seyyed Hossein Nasr that Islamic education must concern to all humans to be educated. The aim is not only to train thoughts but also to train all personal forms. That's why Islam Religion education not only convey knowledge (al-ta'lim) but also to train all students' self (al-tarbiyyah). teacher has function as a mu'allim, knowledge conveyor and as a murabbi, soul and personal trainer.

In the reality, it is not a simple effort but it is a dynamic and full of challenge activity. In the process, education will always be changed according to era change. Everytime, education always be a center of attention and it is often to be unsatifaction target since it relates to all of people interest. It does not only concern the investation and condition of future life but also it 
involves the recent condition. That's why education always requires improvement and escalation efforts according to the higher needs and demands of society life (Fattah, 2004, p. 1). As an education institution, school becomes one of places in which educational process occurs. School has complex and dynamic system. It is not only a place for teacher and students' gatherness but also it exists in comples and related system. School is viewed as an organization which requires management. Moreover, the main activity of school organization is by managing human resource which is expected to result qualified graduates based on society demands and the school graduates are also expected to give contribution for national development (Fattah, 2004, p. 2).

Islamic education institution must be able to bring its students to the moderate religion understanding. As long as the religion understanding is in extreme edge, education will remain peripheral and marginal. To increase and form citizen character who is able to respect those difference, it is required an educational concept for pluralism and multicultural. In the context of plural Indonesian society, the understanding of pluralism reality, apparently, has been a necessity that cannot be ignored anymore. Since the use of "single paradigm" in solving many social problems is no longer effective. Pluralist/multiculturalist Islamic education is an education which develops character that is able to appreciate opinion and different habituals or contradictive with one's faith as well as to own flexibility in interaction with his surrounding environment.

Democration education needs to be developed as an effort to cretae more democratic society. Such education will appreciate individual rights including freedom of thought, united, opinion, and fear. These efforts are urgently required to create national cohesiveness and citizen's commitment in developing democratic unity country. Democration education initiated in Islamic education institution is intended to be more emphasized on implementing democratic, tolerant, open, sincere in accepting difference, and willingnes to listen and to give opinion elegantly and politely as well as intelligently and maturely. This is similar to the condition of Indonesian people who face social crisis which is quite worrying nowadays.

Modern life characteristics is showed by the more rapid changed and more complex. Therefore, it is required a learning model which can develop a sensitivity toward the change without losing self identity and creativity as well as profesionality to respond many challenges.

Islamic education institution is demanded to be responsive against modernization which have been existed in general school institutions under Ministry of Education. Besides developing sensitive character toward the change through apporiate learning strtategy and develop children psycho- 
social condition, it also modernizes learning facilities, environment, and other supporting factors including the involevement of parents, government, society and other education stakeholder. Thus, it is expected that Islamic education institution in Indonesia can promote, develop, and implement education and learning model to strengthen inclusive Islamic education system which is opened, dialogic, and student-centered. This is intended that Islamic education can bear a strong and tough human reseource with high tolerance who will act to occupy and create new civilization emphasizing on religion, spritual and humanism values.

Besides, Islamic education institution can develop networking and corporation both national and international to expand informationn access, funding, and other international supports. Thus, Islamic education is no longer "suspected" as radicalism and fundamentalism agent. Otherwise, it can create a harmony life together and give solution to the more complex life problems (Aan Hasanah, Model Pendidikan Inklusif, Media Indonesia, Mrch 4 th, 2010).

\section{CONCLUSION}

Islam's doctrine for harmony is one of actualization of tasamuh (tolerance). Since the harmony of religious life is one of tolerance forms taught by Islam, so, it must realize in society life. In the context of plural Indonesian people in form of tribes, cultures or religions, principles and attitudes of life for mutual respect, understanding, corporation, fair, honesty, accountability (responsibility and willingness to accept the consequence of his action), integrity (moral sincerity and ethic behavior) and the truth that humans as religious creature in which everyone has rights to choose different faith, it becomes basic principle in developing the united, harmonous, and civilized society. These harmony principles can be established if the society has awareness toward the principles. Indeed, such awareness requires process through knowledge, comprehension and practice (habitual). Tolerance and harmony in Islam have harmonous values whic can be classified into three aspects, among others: consciousness of Allah's existence, relationship, and characters which shows harmony. The consciousness of Allah's existence shows the unity of God (taubid) which becomes primary element in developing harmony among religion adherents; relationship aspect shows that Islam puts forward universal humanity; whereas harmonous character refers to practical value and as the extansion of the previous aspects. Islamic education must be able to bring its students to moderate and inclusive religious understanding. As long as the religion understanding is in extreme edge, education will remain peripheral and marginal. To increase and form citizen character who is able to respect those differences, it is required an 
educational concept for pluralism and multicultural. In the context of plural Indonesian society, the understanding of pluralism reality, apparently, has been a necessity that cannot be ignored anymore. Since the use of "single paradigm" in solving many social problems is no longer effective. Islamic education institution is demanded to be responsive against modernization which have been existed in general school institutions under Ministry of Education. Besides developing sensitive character toward the change through apporiate learning strtategy and develop children psycho-social condition, it also modernizes learning facilities, environment, and other supporting factors including the involevement of parents, government, society and other education stakeholder. Thus, it is expected that Islamic education institution in Indonesia can promote, develop, and implement education and learning model to strengthen inclusive Islamic education system which is opened, dialogic, and student-centered. This is intended that Islamic education can bear a strong and tough human reseource with high tolerance who will act to occupy and create new civilization emphasizing on religion, spritual and humanism values. Islamic education institution can develop networking and corporation both national and international to expand informationn access, funding, and other international supports. Thus, Islamic education is no longer "suspected" as radicalism and fundamentalism agent. Otherwise, it can create a harmony life together and give solution to the more complex life problems.

\section{BIBLIOGRAPHY}

Andito (ed), (1998), Atas Nama Agama, Pustaka Hidayah, Bandung

Arnold, Thomas, W. (1993), The Preaching of Islam: A History of The Propagation of The Muslim Faith, 2nd ed. London: Constable and Co. Ltd

Atoshoki, Antonius, et.al, (2006), Relasi dengan Tuban, PT Elex Media Komputindo, Kelompok Gramedia, Jakarta

Azra, Azyumardi, (2006), "Bingkai Teologi Kerukunan Hidup Antarumat Beragama : Perspektif Islam", salah satu tulisan yang terdapat dalam buku, Weinata Sairin, (Penyunting), Kerukunan Umat Beragama Pilar Utama Kerukunan Berbangsa, Butir-Butir Pemikiran, BPK Gunung Mulia, Jakarta

Baalbaki, Rohi., (2004), Al-Mawrid: A Modern Arabic English Dictionary, Beirut: Dâr El-Ilm Lil Malâyîn

Bagus, Lorens., (1996), Kamus Filsafat, PT. Gramedia Pustaka Utama, Jakarta

Bakar, Osman and Nai, Gek, Cheng., (1997), Islam and Confucianism, A Civilizational Dialogue, University of Malaya press, Kuala. Lumpur

Daja, Burhanuddin and Beck, Leonard, Herman (red.), (1992), Ilmu Perbandingan Agama di Indonesia dan Belanda, INIS, Jakarta 
Departemen Pendidikan dan Kebudayaan, (1985), Kamus Besar Bahasa Indonesia, Balai Pustaka, Jakarta

Eliade, Mircea, (ed), (1987), Encyclopaedia of Religion, vol.12' MacMillan Publishing Company

Fattah, Nanang., (2004), Konsep Manajemen Berbasis Sekolah (MBS) dan Dewan Sekolah, Pustaka Bani Quraisy, Bandung

Gauhar, Altaf (ed), (1983), Tantangan Islam, terjemahan Anas Mahyudin, Pustaka, Bandung

Ghazali, Muchtar, Adeng (2005), Ilmu Studi Agama, Pustaka Setia, Bandung Hamka, (1983), Tafsir al-Azhar, Juz III. Pustaka Panjimas, Jakarta

Negara Terancam Serius. (2011, Jum'at, 29) Harian Umum Pikiran Rakyat, p.

Harmoni, Jurnal Multikultural \& Multireligius, Vol. III, Nomor 9, JanuariMaret 2004, Puslitbang Kehidupan Beragama, Badan Litbang \& Diklat Keagamaan Depag RI

Hasanah, Aan, (2010), Model Pendidikan Inklusif, Media Indonesia, 4 Maret

Hendropuspito, D., (1983), Sosiologi Agama, Kanisius, Yogyakarta

Jurnal Ulumul Qur'an, No.1 Vol.IV, Th. 1993

Kartika, Sandra., \& Mahendra, M. (ed.) (1999), Lembaga Studi Pers \& Pembangunan, Jakarta.

Kodir, Abdul, M. (1993), Islam Konseptual dan Kontekstual, Itqan, Bandung

Ma'arif, Syamsul. (2006), "Islam dan Pendidikan Pluralisme, Menampilkan Wajah Islam Toleran melalui Kurikulum PAI berbasis Kemajemukan”, Makalah yang disampaikan dalam Annual Conference Kajian Islam, Lembang Bandung, 26-30 Nopember

Madjid, Nurcholish., (1992), Islam, Dokrin, dan Peradaban, Paramadina, Jakarta

Madjid, Nurcholish., (1997), Tradisi Islam, Peran Dan Fungsinya Dalam Pembangunan di Indonesia, Paramadina, Jakarta

Madjid, Nurcholish., 1995), Islam Agama Peradaban, Membangun Makna dan Relevansi Doktrin Islam dalam Sejarah, Paramadina, Jakarta

Majalah Prisma 5, Juni 1978

Mujani, Saeful. (n.d). Muslim Demokrat, Islam, Budaya Demokrasi, dan Partisipasi Politik di Indonesia Pasca-Orde Baru, Gramedia, Jakarta

Nafis, Wahyuni, Muhammad,. (editor), (1996), Rekonstruksi dan Renungan : Religius Islam, Paramadina, Jakarta

Permata, Norma, Ahmad, (ed), (2000), Metodologi Studi Agama, Pustaka Pelajar, Yogyakarta

Poerwodorminta, W. J. S. (1996), Kamus Umum Bahasa Indonesia, Jakarta: Balai Pustaka.

Rachman, Munawar, Budhy, (2001), Islam Pluralis, Wacana Kesetaraan Kaum Beriman, Paramadina, Jakarta 
Rachman, Munawar, Budhy, (2001), Islam Pluralis, Wacana Kesetaraan Kaum Beriman, Paramadina, Jakarta

Rahman, Almasdi, Toleransi dalam al-Qur;an, etext, data diambil dari http://www.mailarchive.com/jamaah@arroyyan.com/msg03522.html, pada hari Rabu tanggal 17 Maret 2010.

Rasyidi, M., (1968). Al-Djami'ah, Nomor Khusus, Mei, Tahun ke VIII.

Sairin, Weinata (Penyunting), (2006), Kerukunan Umat Beragama Pilar Utama Kerukunan Berbangsa, Butir-Butir Pemikiran, Jakarta: BPK Gunung Mulia,

Schumann, H, Olaf,. (2006), Menghadapi Tantangan, Memperjuangkan Kerukunan, BPK Gunung Mulia, Jakarta

Shihab, Alwi, (1999), Islam Inklusif, Mizan, Bandung, 1999

Sirry, A, Mun'im., (2004), Figh Lintas Agama; Membangun Masyarakat InklusifPluralis, Paramadina, Jakarta

Sumarthana dkk., Th. (ed.) (n.y.), Dialog: Kritik dan Identitas Agama, Penerbit Dian/Interfidei

Tarsyah, Adnan, (2008), Manusia yang Dicintai dan Dibenci Allah, Mizan, Bandung

UNESCO-APNIEVE, (2000), Belajar Untuk Hidup Bersama Dalam Damai Dan Harmoni, Kantor Prinsipal Unesco untuk Kawasan Asia-Pasifik, Bangkok, dan Universitas Pendidikan Indonesia

Wahyudin, dkk., Pendidikan Agama Islam Untuk Perguruan Tinggi, Bandung: Grasindo.

Yusuf Al-Qaradlawi, (1997), Fiqib Peradaban, Sunnah Sebagai Paradigma Ilmu Pengetabuan, translated by Faizah Firdaus, Surabaya: Dunia Ilmu. 